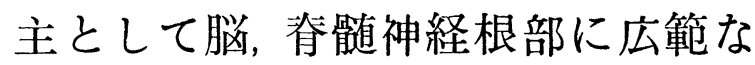 転移を示した胃癌の 1 剖検例
}

\author{
佐藤和雄 直田靖彦 佐川公夫 \\ 群馬大学医学部第一病理学教室 (主任 川合貞郎教授)
}

\section{緒言}

悪性腫瘍の脳, 脊髄軟膜へのびまん性転移は 1880年 Oppenheim によってはしめて記載され 1901年 sänger の報告以来注目され，しだい に報告例も増し,びまん性転移性軟膜癌腫症 (Metastatic diffuse meningeal carcinomatosis）あるいは，いわりる癌性脳膜炎（Meningitis carcinomatosa) として総括されている. 本症の原発巣の大半は胃癌であるが，それによ

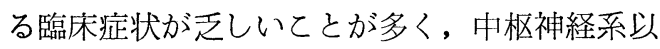
外の藏器転移も極めて少いため, 中枢神経系の 病変による症状が前景に立ち, 正確な臨床診断 をつけ難いてとが多い点が注目されている。ま た本症でかなり撰択的な脳, 脊娟迶神経への転移 を伴う稀な症例も報告されているが，いずれに しても原発巣から中枢神経系への転移径路をめ ぐって諸説があり， ${ }^{1,4}$ ) 特にての点に興味ある 問題が残されている。著者らは最近おもに脳, 春顝神経根部に広範な転移を示した, びまん性 軟膜癌腫症の類型と考えられる 1 例を経験した ので病理組織学的に検索し, 興味ある転移分布 と転移径路を中心に若干の考察を加へて報告す る.

\section{臨 床 所 見}

患者: 48才, 女性.

主訴: 歩行障害, 意識消失発作, 頭痛.

経過概要：1962年6月20日頃よりめまい, 榈时, 頭痛, 複視と腰部から両滕部屈側にかけての疼痛があらわれ 7月24日頃には失調性の歩行障害も加わってきた. 某 院整形外科で坐骨神経痛と誩断され牽引療法を受けた ことがある．上記症状は持続し 8月上旬には1日1〜
3 回の発汗々両下肢のしびれ感を伴う数秒間の意識消 失発作があらわれ，しだいに回数を増し，下旬には1 日3〜4回にも及ぶようになり群大石原外科六し た.

入院時所見：悪心，嘔吐，頭痛を訴光，両下肢は完 全に麻痺して挙上できず，両上肢のしびれ感や右臍下 部之左下肢の痛覚鈍麻が認められた。複視, 瞳孔不同 （左>右）, 両側の軽度のうつ血乳頭（左>右）, 右 動眼神経の部分的不全麻痻も認められた. 反射は腹壁 反射消失のほか济諸腱反射は正常で理学的に胸, 腹部 亿著変はない，血圧は140〜80 $\mathrm{m}, \mathrm{mHg}$.

入院後の経過 : 発作性の意識消失はみられないが， 覀心, 嘔吐は持続, 8月23日髄液検查で Goldsol reaction が神経梅毒型に類似し，ワ氏反応も強陽性で あった. 24日咳嗽, 喀痰があり, 悪心, 嘔吐は消袾し たが, 食思不振となり, 29日には項部痛, 頭痛, 両上 肢しびれ感, 発熱 $\left(38^{\circ} \mathrm{C}\right)$, 左肺野にラ音を認め, レ線像で左下肺野にびまん性陰影を認めた。抗生物質, 強心剂, 酸素吸入を行ったが, 呼吸不整, 喀痰増加し 9月1日午前突然呼吸麻痺を呈して死亡した.

全経過: 症状発現上り約2.5力月.

既往歴：25才某医に梅毒性ラツパ管炎といわれたて とがある。共なし。

家族歴: 父70才脳卒中で死亡, 母精神病で死亡, 兄 弟 5 人中 2 人肺結核で死亡. 夫 46 才脳梅毒で死亡. おもな臨床検査事項：脊髄液（8月23日）; 圧 $300 \mathrm{mmHg}(-7 \mathrm{cc}) \rightarrow 70 \mathrm{mmHg}$, 透明, Xanthochromie (t), Pandy ( + ), Nonne-Apelt ( $($ ) $)$, Protein $(+)$, Gold-sol reaction 神経梅毒型に類似, 口氏反 応 (卅). X線; 左頸動脈撮影で異常所見はない. 左下 肺野にびまん性陰影が認められる。血液所見（7月30 日）; 血色系（sahli） $90 \%$, 赤血球数 $474 \times 10^{4}$, 血球 数 7700 , リンハ球 $11 \%$, 単球 $3 \%$, 好酸球 $2 \%$, 病的 細胞 (一), If I 沈 $37 \mathrm{~mm} / 1 \mathrm{~h}, 66 \mathrm{~mm} / 2 \mathrm{~h}$, 血清蛋白 
6.8g/dl。（8月23日）血色素88\% (Sahli), 赤血球数 $469 \times 10^{4}$, 白血球数 11200 , 口氏反応 $(-)$. 肝機能; M. G. $9 \times$, 高田 4, BSP 7\%(45), TTT 3. 尿 所見; 黄白色混濁, 蛋白 (一), 糖 (一), ウロビリ, 一ゲン (-), 沈渣赤血球 $1 \sim 2 / F$, 蓚酸石灰, 尿酸 塩 $(+)$.

病理解剖学的所見 (No. 1656)

1. 胃癌. 胃体部小彎側における $1 \times 1 \mathrm{~cm}$ 円 形 2 個の潰瘍と幽門部における $1 \times 1 \mathrm{~cm}$ 円 形結節状腫瘤形成。胃壁全体の灰白色混濁肥 厚.

2. 脳脊髄に広範に認められる神経根部の灭白 色, 膠様肥厚, 春髄軟膜の軽度の混濁と髄液 の增量.

3. 癌転移. 胃周囲リンパ節, 後腹膜 リンパ 節, 腹膜 (おもに骨盤), 左副腎, 左卵夈, 子宮.

4. 左肺下葉のうっ血と灰白色実質性, 硬度の 増加.

胃内容は黄褐色, 半流動性, 粘膜面には多量の 粘液が付着し, 蚐譬は腫脤し埾度の粘膜下点状 出血を伴っている. 幽門輪より口側 $3.5 \mathrm{~cm}$, 大 彎側に $1 \times 1 \mathrm{~cm} 2$ 個の浅い円形潰瘍が認めら れ皺譬はこの部に集中して走り, 壁は灰白色に 肥厚し, 堤防状に隆起し底には黄白色の Belag を付着している（図1）。穿孔は認めないが, 漿膜面に $2 \times 2 \mathrm{~cm}$ の腫瘍性浸潤がある(図 2 ). さらに幽門輪に一致する小彎側に直径 $1 \mathrm{~cm} の$ 腫瘤を認めるが, 強い狭窄はない。この部の漿 膜は大網, 脺体部と強く癒着し一塊となってい る. 局所リンパ節には異常腫大はないが, 割面 は灭白㵦様で硬度も高く腫瘍浸潤を思わせる。 腹水に著変なく，骨盤腹膜およびこの部の小腸 漿膜にアズキ大の小結節が散在している。春蹎 液は淡黄色透明, 軽度に增量し脊鹃神経束は 頸, 胸, 腰ともに硬度を増し灭白半透明にみえ 太くなっている(図 3).乙の変化は殊に神経根 部に強く, 腰神経, 馬尾神経ではところどてろ しゅず状の結節性肥厚を示し, 硬膜を越えて未
梢側にまで及んでいる（図 4）。乙れらの神経 束には周囲骨との癒着はみられず,ままた骨自体 にも腫瘍転移を思わせる所見はない，硬膜には 肥厚, 混濁をみないが, 軟膜にはびまん性, 雗 度の混濁肥厚が認められる。春㵦は全般にやや 細くなっているが, 割面では正常構造がよく保 たれ，限局性の変化は認められない。大脸は $1290 \mathrm{~g}$, 底部および弓部の軟膜や脳底動脈には 著変はなく, 大脳前額断のいずれの割面にも腫 瘍転移を思わせる限局性変化はなく, 貧血性で ある. 特徴的所見は脳神経に認められ I, II 神 経を除くすべての脳神経束には脊娟神経所見と 同様に灰白色膠様肥厚があり, 殊に根部に強く 認められる（図6）。特に両側の三叉神経, 動 眼神経, 左顔面神経, 内耳神経に病変が強く, その口径は正常の数倍にも及んでいる.

\section{病理組織学的所見}

胃の潰瘍部は物質欠損が筋層にまで達してお り, 潰瘍底には著明な癌細胞浸潤がある。癌細 胞浸潤は潰瘍周囲に残る粘膜下織から筋層, 漿 膜下織にまで及び, ところどころで結合織の增 生を伴い, 漿膜面に結節状の隆起をつくってい る. 潰瘍周囲の粘膜は正常構造が失われ, 粘膜 層内に著明な腫瘍浸潤があるが，その一部には 正常粘膜組織が島状に残っているとてろがあ る（図 7)，腫瘍細胞は強い多態性，異型性を 示し, 多核巨細胞, 核分裂を示す細胞を混して いる. 腫湢細胞の多くは胞体が泡状ないしエ才 ジンで赤く強染し, 多数の印環細胞を混してい る. 腫瘍細胞には特定配列はほとんど認められ ずびまん性浸潤の型をとり粘液変性傾向の強 い細胞からなる単純癌の所見を示している（図 8）. 腫瘍状に粘膜面に突出した部分では, 粘 膜欠損はないが, 粘膜層の正常構造は全く失わ れ前記同様の異型的な細胞がびまん性に増殖し ており, 同部の粘膜下織にも結合織の増生を伴 って著しい腫瘍細胞浸潤があり, 全体として結 節状をなしている。乙こでは腫瘍細胞はやや集 
簇する傾向を示し, 不完全な腺様構造を示すと ころもある。同様の浸潤は同部の筋層内にも愨 められる. 胃壁内の腫瘍組織は壁内神経谈や神 経束内に強く浸潤している所があるが,リンパ 管腔や血管内に明らかな腫瘍血栓をなして侵入 しているとてろはない。

\section{転 移 組 織 所見}

1.a）脊鹃および春咀有神経. 肉眼的に口径を増 し灰白膠様にみえた春㵦全長にわたる神経根部 は前, 後根とも神経線維を押し開くように癌細 胞が強く浸潤し,そのために髄鞘には変性, 消 失にいたる種々の病変が認められ, 癌細胞は胃 におけると同様びまん性増殖の形をとり, 大部 分は印環細胞化している（図 9 ）。髄鞘変化の 強い部分には多数の Gitterzellenを混じている. 腫瘍浸潤は根漏斗部 (Eintrittsporte) にまで 及んでいるが，実質深く浸潤する所見は認めら れず，ての部の境界は比較的明瞭である(図9). 軟膜はやや線維性に肥厚しおもに前, 後根部の 軟膜に軽度ないし中等度のびまん性腫瘍浸潤が みられるが，その程度は神経束内浸潤に比して かなり弱い．神経束内浸潤は末梢側にも連続性 亿認められ，硬膜を越えて髄腔外にも及んでい る. 硬膜では腰髄部に軽度に認めたほかは検索 範囲内では癌細胞は見出されなかった。脊髄実 質はいずれの割面でもほぼ同様所見で，根漏斗 部の癌浸潤境界部にェオジンで濃染, P. A. S. 強陽性, 脂肪染色陰性の索状ないし板状の不規 則な均質無構造の蛋白様物質の沈着が集簇して みられ，類澱粉小体も多数出現している。その ほか実質および実質内血管などには癌細胞は全 く認められない. 前角神経細胞には強い色素沈 着を伴う膨化を示すものが多く，一部には融解 消失にいたる強い変性や Neuronophagie が認 められ, 後角神経細胞には核の濃縮, 細胞の細 長化がみられ，周囲組織にうっ血と転度のGliose を伴っている. 白質の線維は比較的よく保 たれ脱髄所見は認められなかった。馬尾神経は
肉眼的にじゅず状, 結節状肥檿を示していたが これは著明な癌細胞浸潤によるもので，その大 部分は印環細胞であり，著しい䯣鞘の変性，崩 壊, 疎開, 多数の Gitterzellen の出現を伴って いる（図11）。以上いずれの部分においても腫 瘍血栓は認められず，腫瘍細胞と血管との密接 な関係を思わせる像はない。

b）脳および脳神経．肉眼的に嗅索，副神経 を除くすべての脳神経根部に口径の増加を認め たが，組織学的に検索しえた神経束の癌細胞浸 潤は次の如くである。嗅索および嗅球 (一)， 視神経 $(+)$, 動眼神経 $(+)$, 三叉神経 $(+)$, 外転神経 $(+)$, 顔面神経 $(+)$, 迷走神経 $(+)$. 視神経は根部付近のみで交叉部には認められな いが，末梢側の髄膜には強い浸潤を示す部分が ある．癌浸潤の状態は脊髄神経根におけると同 様であるが, 特に動眼, 顔面神経に強く, 浸潤 はいずれも漏斗部でとどまり深部脳実質内に深 く侵入する像はない（図10）。神経根部周辺 の軟膜への浸潤は脊髄に比して極めて軽度であ る.脳幹部の神経諸核には変性を認めるが, 脊 娟迶神経細胞のそれに比して軽度である. 大脳半 球弓部の軟膜は軽度の線維性肥厚と充えい拡張 した血管をみるが,一部に集簇した軽度の癌細 胞浸潤をみるとてろもある，大脳実質は小血管 周囲の軽度の浮腫と小円形細胞浸潤をみるが, 神経細胞変性は軽度で, 癌細胞の浸潤はない。 皮質下核でも血管の強い充えい拡張をみるほか は神経核, 線維には著変をみない。脳室系は第 III 脳室脈絡叢の一部の血管周团に軽度, 第 $\mathrm{V}$ 脳 室上壁とてれに接する脈絡叢内に強い腫瘍浸潤 があり，室は軽度に拡張している（図12）。側 脳室，中脳水道壁は検索範囲内では著変をみな い. 脳脚部軟膜は血管の充えい拢張が強く, 癌 細胞は血管を取り囲むように浸潤し，血管壁は locker ödematös に疎開してみえる. 黒質神経 細胞のPigment もよく保たれ, 神経線維にも著 変をみない。小脳は葉間溝軟膜の一部に印環細 胞の集簇して増生する部分があり，ての部の血 
管は増生し強く昖掁, 充えいしているが, 血管 壁, 腔内には癌細胞は認められない。浸潤は一 部皮質表層に欢でいるが，深く侵入する像は なく，小脳皮質神経細胞はよく保たれている。 大脳, 小脳硬膜を数個所検索したが, 癌細胞は 認められなかった。下垂体は強いうっ血を示す ほかは著変なく, 後葉, 被膜および隣接硬膜に も癌細胞浸潤はない。

c) 脳神経末梢部。舌神経末梢 (舌部), 横 隔神経 (縦隔洞部) いずれも癌細胞は認められ ない。

2. 中枢神経系以外の転移組織。いずれの転移 臟器でも腫瘍組織像は原発とほぼ同様で印環細 胞が大半を占めており, 部位によって浸潤程度 に差がみえるのみで特異な像はみられない。

a）リンパ節. 胃局所, 肝門部, 後腹膜, 腸 間膜等のリンパ節はいずれにも高度の腫大はな く, 既存のリンパ節構造を比較的よく保ってい るが，拡張したリンパ洞内に強い浸潤がある。 腰椎周用, 骨盤リンパ節では正常構造を失い, 線維化を伴うものが多く, 周囲リンパ管内に腫 瘍栓塞を強く認める点が特徵的である.

b) 腹膜わよび後腹膜組織. 盲腸壁に散在す る米粒大結節は粘膜下織に浸潤する癌組織が, 一部腺様構造を示し, 線維性基質を伴って ski一 rrhösに増殖しているが, 漿膜に強い浸潤は認 められない。骨盤腹膜に散在する小結節も同様 所見で, 線維化を伴ったびまん性浸潤である。 後腹膜で最も腫瘍性変化の強い部分は左副腎で 髄質に強い充実性の癌細胞浸潤と被膜の癌性, 線維性肥厚を認め内部に包埋された多数の血管 には全層に強い浸潤があり，血管壊死の認めら れるところもある. ての部の神経節内にも多数 の癌細胞を認め, 線維化を伴って正常構造はか なり乱れている．副腎皮質のリポイド量は一部 に斑状消失をみるほかは比較的よく保たれてい る.

c）骨盤臟器。子宮, 左卵栄にも腫瘍転移を みるが, 子宮内膜のポリープは腺增生を伴う粘
膜の限局性把原によるもので, 腺上皮には覀性: 化所見はない。しかし固有層のところどてろに 極めて細胞性の部分があり, 胞体の広い, 多態 性の著しい細胞がびまん性に増生し, 細胞のあ るものには粘液変性傾向が認められる，外膜に かけても同様細胞が，とてろどてろで集簇をつ くって増生し, 外膜は線維性に肥厚し, 癌細胞 の skirrhös な浸潤を伴っている。一部の血管内 に明かな腫瘍血栓を認めるが，一般に腫瘍細胞 と血管との密接な関係はない。左卵巣は白体 化, 線維化の強い萎縮像を示し, 癌細胞は一部 腺樣構造を示し, 線維束内にびまん性に浸潤し ている，骨盤内結合織内に認められる末梢神経 束を一部検索したが，いずれにも癌細胞は認め られなかった。そのほかのおもな副病変として 頸部および静脈角りンパ節, 肝小葉内にフイブ リンの柝出, 乾酪化を中心に Epitheloidzellen, ラ氏型巨細胞からなる栗粒結核結節を認めた。 肺実質内には結核病変は見出せなかった。腰骨 々髄や椎間板および腰交感神経節には周囲のリ ンパ節, 神経根, 硬膜に強い癌性浸潤を認める 部分でも検索範囲では癌細胞を証明できなかっ た。

\section{総括および考按}

脳脊髄軟膜のびまん性転移性癌腫症に関す る従来の記載をみると, 統計的は共通した興味

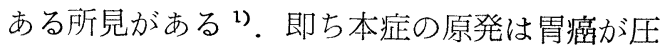
倒的に多く，また胃癌の中枢神経への転移の大 部分がこの型をとること, 原発巣は幽門部付近 に多く, 潰瘍化傾向を示し, しばしば癌浸潤が 極めて広範に胃壁におよび, 病理組織学的に Adenocarcinoma が大半を占める点などであ る. 本例の胃原発巣としては, 幽門部に小潰 瘍, 小腫瘤の形成がみられ, 潰瘍は癌組織の崩 壊によるものであるが，比較的浅く，強い幽門 狭窄や潰癔からの出血も認められない，小腫瘤 部でも浸潤はびまん性に壁全体におよび，壁の 限局性肥厚を示しているが, その程度は軽く, 
(166)

その部の粘膜層もよく保たれ，びまん性の癌細 胞增生を示す部分と, 正常粘膜構造を示す部分 とが混在しており，胃における癌性変化として は極めて軽い部類に層する。臨床的にも胃症状 に乏しく，全く胃癌を気付かれずに経過した点 は病理学的所見と一致するようにも思われる。 病理組織学的にはCarcinoma simplex mucocellulare で総括されるが，粘膜病変の割合に胃 壁深層殊に嶈膜にまで強く浸潤する傾向が強い こと, 一般の胃癌例にしばしば認められる壁内 血管, リンパ管への侵入像がほとんどみられず に, 神経叢や神経線維束内への侵入像を認める 点がやや特異である。本症を発生せしめる転移 径路には次の方法が考えられている。すなわち 第 1 亿癌細胞が血行路により脳, 脊髄実質, 脈 絡叢, 脳脊髄膜などの一部に転移し, てれより 脳, 脊鹃膜に浸潤, 播種される。乙の場合には 頭蓋, 脊椎内転移の最初の部位に結節をつくる ことが多いといわれる。第 2 の径路は癌細 胞が脳神経, 脊咀神経根周囲のリンパ腔を介し て頭蓋または春椎内に侵入し，くも膜下腔に播 種される。第 3 亿神経系組織周囲の骨に転移し その部の神経に連続性に発育浸潤する径路であ る。本症の転移分布が一般の胃癌例と異なり, 肝, 肺に極めて少く, 骨盤腹膜, 脊椎周囲リン パ節などに強いことから腫瘍蔓延径路として第 2 の神経周囲リンパ路を考える研究者が多く, Marchand, Pette, Peneche, Kino, Alpers とsmith, 寺本, 三村，光野 ${ }^{4)}$, 所 ${ }^{1)}$ な゙はての 径路によると考えられる症例を報告している. 実験的には血行性以外の転移径路について吉田 肉腫を坐骨神経幹周囲に移植した研究があり, 神経幹の外側に沿って椎間孔より神経実質およ び脊椎管内, 硬膜内外に侵入するが, くも膜よ り内部には浸潤しないという報告がある ${ }^{6)}$. 本 例はこの転移径路説明にいささか興味ある所見 を示しているように思われる．本例の転移分布 を図に示すと大略次の如くである。

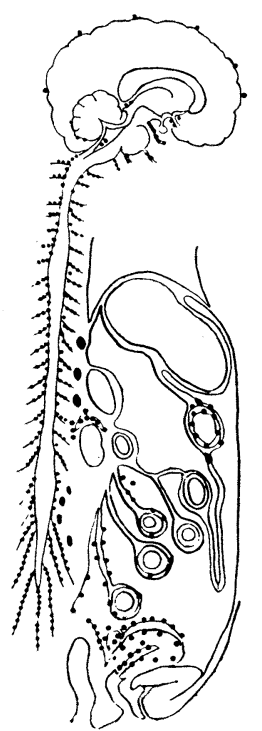

中枢神経系以外の転移は骨盤腹膜, 骨盤臓器で 卵单, 子宮内膜に侵入する傾向が強く, 後腹膜 ではリンパ節に強く，異常腫大はないが，骨 盤, 腰部大動脈, 腰椎に接する小リンパ節に強 く浸潤している点である. 胸部, 静脈角および 頸部などの上部りンパ節にはいずれも転移を証 明し得なかった。転移巣の組織像は一部に多少 腺腔を囲む傾向や線維性基質の增生を伴う部分 はあっても, 原発とほぼ同様所見で特定配列傾 向の少い印環細胞が腫瘍組織の大半を占める単 純癌の像である. 拡張したリンパ洞内に強く侵 入する像が特徵的で, 血管内侵入像は極めて少 く, 明かな腫瘍栓塞を認めたのは左副腎髄質, その被膜内血管と子宮外膜の一部の血管のみで ある. 転移径路検索の目的で骨盤周囲, 腰椎周 囲結合織内の神経線維束や神経節を検索したが いずれにも明かな癌細胞はみられず, 強い浸潤 転移を示す小リンパ節に接する部分でも認めら れない，左副腎囲囲神経節および線維束で, 腫 瘍組織に包埋された部分では極めて強い浸潤を みるが，線維束を押し開くように連続性に侵入 する像はない，末梢側から検索した舌神経, 横 隔神経, 閉鎖神経にも全く腫瘍細胞は見出され 
なかった。中枢神経系で腫瘍浸潤を強く認め た部位は脳, 脊髄神経根部で, 検索した範囲内 では嗅神経以外すべてに広範に認められ, 春髄 神経では馬尾に強く, 結節状の肥厚を伴ってい る.さらに浸潤は軟膜にもびまん性に認められ 脊髄に強く, 大脳では比較的弱い。神経根部に 強く浸潤した部分でも, 漏斗部に一部入り込ん でいるほかはいずれの部分でも実質内に深く侵 入する所見はない。神経束内浸潤は硬膜を越え てさらに末梢側にまで強く侵入する部分もある が, 硬膜内浸潤を認めたのは腰䯣で軽度散在性 であつた。この部の腰椎骨髄, 椎間板, 腰椎周 囲軟部組織の癌細胞は認められない。

本例は Diffuse meningeale Karzinomatose の 1 類型ではあるが, 従来の症例と異り病変の 主座が脳, 脊髄神経根部に広範な転移を示す点 で、いかなる径路で髄腔内に侵入したかという 点に興味がもたれる.脳, 春髅神経への転移を伴 う悪性腫瘍の症例は頭蓋底, Ganglion Gasseri に初発転移巣を形成し, 求心性, 連続性に一 部の神経に浸潤する例 (Marchand, Jurcev, Henschen), 局所から視神経鞘あるいは嗅球, 嗅糸への浸潤例（Raskind）をみる程度で広範 な転移を伴う報告はないようである. 本例は肉 眼的にも, 検索した組織像でも, 春椎や頭蓋か ら連続性に骨を破壊して硬膜に達した所見や, 脳実質に結節状転移を生し二次的に㵦腔に拡が ったと考え得る所見も見出せない．また臓器内 末梢神経から求心性に髄腔内に侵入発育する所 見もない.肝, 肺に転移を認めない点と腫湯組 織内の血管と癌細胞との関係がそしい点は一般 の血行性転移例と異なる特徴的所見と考元られ る. 本例の転移様式と比較検討する目的で私の 教室で病理組織学的に, びまん性脳軟膜癌腫症 と診断された 2 例について中枢神経束を中心に 検索を行ってみた。

第 1 例は28才, 男性, 脺頭部の Undifferentiated aciner cell careinoma で局所から後腹膜 に強い浸潤を示したが, 肝, 肺に転移を証明し
得ない症例で脳, 脊髄実質内に腫瘍結節や浸潤 像はないが, 春髄硬膜, 軟膜に強く, びまん性 浸潤を示している. 奉髄神経鞘内に強く侵入す る像を認めるが, 広範な病変はなく, 末梢側に連 続性に浸潤する像もない，原発巣わよび転移組 織像で血管壊死を伴う組織壊死傾向が強く, 血 管, リンパ管内に強く侵入する像が特徴的であ る. 第 2 例は 44 才, 女性, 脳局所解剖のため原 発巣は不明であるが, 中枢神経系の転移組織像 は Carcinoma simplex mucocellulare で脳, 脊髄軟膜に強いびまん性転移があり, 嗅索, 動 眼神経鞘, 三叉神経, 視神経鞘に浸潤を認める が神経漏斗部ないし実質内に深く侵入する像は いずれにもない，第 1 例では肝，肺に転移を示 さず, 一般の悪性腫瘍転移と形式を異にする如 くみえるが，組織像で血行性転移をおもわせる 所見が強く, 脳, 脊髄軟膜のみならず一部連続性 に神経束内に侵入しており，血行性転移之考元 られる例でも詳細に検すると神経根への浸潤は かなり多いのではないかと推察される。第 2 例 は中枢神経系以外の転移分布は明かでないが， 脳, 脊髄腔内に広く播種され同時に多くの神経 束ないし被膜に浸潤し得ることを示しており， 転移組織像が粘液変性傾向の強い単純癌である 点は本例と同様で, この腫瘍組織型と神経束と の親和性も興味ある問題と考えられる。本例は 軟膜のびまん性転移を軽度に伴ってはいるが, 転移の主座はむしろ広範な脳, 脊髄神経根部で, リンパ節転移が特に腰椎周囲に著明に認められ 春髄神経根部の病変と連続的に結びつく組織学 的所見は得られなかったが, 臨床経過で脊髄下 部の症状が初期に出現し, 進行性に持続してい る点を考慮すると, 副腎髄質への転移や一部に みられた腫瘍血栓の形成などから血行路蔓延の 可能性を全く否定するてとはできないが，諸報 告者が指摘している"局所 $\rightarrow$ 腹膜 $\rightarrow$ 後腹膜 $\rightarrow$ 脊 髄神経根周囲リンパ路 $\rightarrow$ 髄腔”の径路が最も考 え易いように思われる。なお肝および肺門, 静 眽角, 頸部リンパ節に莱粒結核病変を認めたが 
(168)

本症の転移形式に関連する所見であるか否かは 明かでない．末期には強い気管支肺炎を伴って 死亡した例と考えられる。

\section{結語}

48才．女性，進行持続する脸，脊髄症状と髄 液検查所見から脳梅毒と診断され，経過中胃癌 に気付かれず, 約 2 か月半の経過をもって死亡 した症例で, 剖検の結果主として脳, 春㵦神経 根部に広範な転移を伴った胃癌例であった。肝 肺に転移を認めず, 骨盤藏器, 後腹膜, 殊に腰 椎周囲リンパ節に強い転移があり，びまん性に 脳, 脊髄軟膜に転移を伴っている点は,びまん 性転移性軟膜癌腫症の 1 類型と考元られるが, 本例では病変の主座が脳, 脊堝道神経根部に広範 な点が極めて特徴的である. 本例の腫瘍蔓延径 路については, 血行性というょり, むしろリン パ行性に後腹膜, 腰椎周囲リンパ節から春髄神 経周囲リンパ路をへて髄腔に達した可能性が強 いことを示唆する所見を得た。これ若干の考 察を加えて報告した。

\section{文献}

1）所 安夫：脳脊䯣軟膜のびまん性転移性癌腫症. 脳腫湯, 521-532, 昭34.

2）所 安夫：転移によつて生じた脳腫瘍。脳腫瘍, 421-437, 昭34.
3）百井一郎：脳転移腫瘍の 2 剖検例. 癌, $43(2-3): 347-349$, 昭28.

4）光野孝雄：びまん性脳膜癌腫症の 2 例. 脳と神経， $5(6): 358-362$, 昭28

5）酒井 等 : 悪性腫煌の転移に関する研究. 名古屋 医学, 73 (3) : 520一, 昭33.

6）伊藤直樹 : 末梢神経幹を上行して脳脊䯣に達する 覀性腫瘍転移径路（吉田肉腫移植による）。日本 外科宝函, 27 (5)：1041-1054, 昭33.

7) Henschen, F. : Sekundire Tumoren der spinalen Wulzeln und Ganglien, in Handbuch der speziellen pashologischen Anatomie und Histologie, ed. by Henke,F., Rössle, R. and O, Lubarsoh, Springer, Berlin. 13 (3) : 945-948, 1955.

8) Danisch und Nedelmann : Bösartiges Thymom u. s. w. mit eigenartiger Metastasierung ins Zentralnervensystem. virchows Arch. 264, 492, 1928.

9) Okazaki, T. : Metastatic malignant tumors of the cranial basis, Brain and Nerve, I (3) : 7-10, 1949.

10) Shanthavearappa, T. R. and G. H. Bourne : perineural Epithelium of sympathetic Nerves and Ganglia and its Relation to the Pia Arachnoid of the central nervous System and Perineural Epithelium of the peripheral nervous System. Zeitschrift für Zellforschung. 61 : 742-753, 1964. 


\title{
SUMMARY \\ AN AUTOPSY CASE OF GASTRIC CARCINOMA WITH MULTIPLE METASTASES IN THE SPINAL AND CRANIAL NERVE-ROOTS
}

\author{
Kazuo Sato, Yasuhiko Suguta and Kimio Sagawa. \\ Department of Pathology, School of Medicine, Gunma \\ University (Director: Prof., Sadao Kawai).
}

This case of cancer of the stomach was reported because of unusual multiple metastases in the spinal and cranial nerve-roots. A 48 aged woman was admitted with chief complaints of disturbance in gait, intermittent attacks of faintness and headach. During the course she had had no uspect of the stomach and bowels, and was diagnosed as having neurosyphilis on the ground of signs of progressive cerebrospinal irritations and positive serologic test for syphilis in the spinal fluid. She died about 3 months after the onset of symptoms.

Necropsy disclosed diffuse thickening of the whole stomach wall with formation of superficial ulceration and small tumor nodule. Microscopiscally the tumor tissue was made up of diffusely infiltrating cells mainly of signet-ring-cell structure (Carcinoma simplex mucocellulare). By the way of lymphatic and transcoelomic dissemination metastases were formed in the retroperitoneal lymphnodules and pelvic organs. Tumor cells made also a prominent invasion upon the spinal and cranial nerve-roots, as well as upon the leptomeninges. Examinations of the peripheral nerves disclosed diffusely infiltrating tumor cells along the nerve sheaths. Their proximal growth, however, were found restained by the terminal zone of the spinal horn.

It seems reasonable to conclude that malignant tumor cells may reach the spinal cavity through the rout along the perineural lymphspaces rather than by the blood-stream. 
(170)

肉 眼 的 所 見

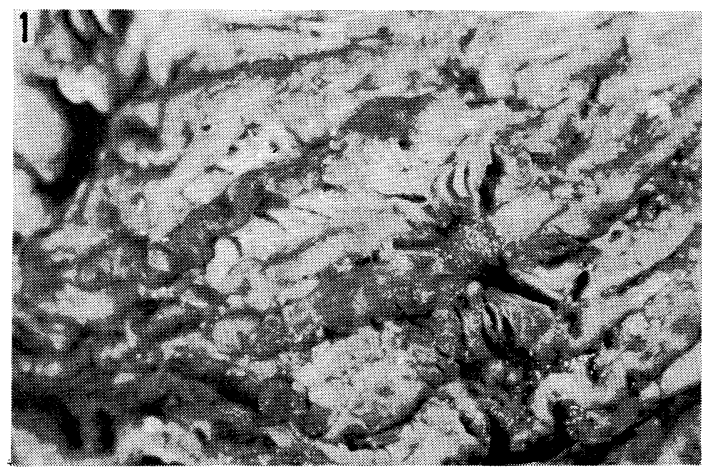

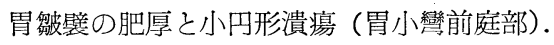

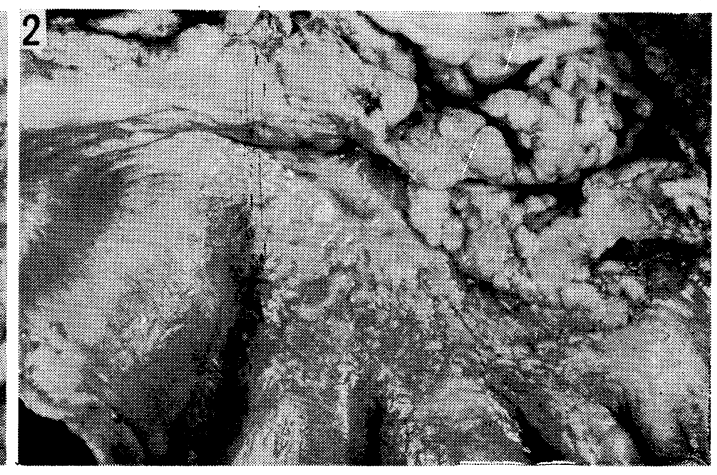

胃小彎漿膜の灰白色混濁肥厚.

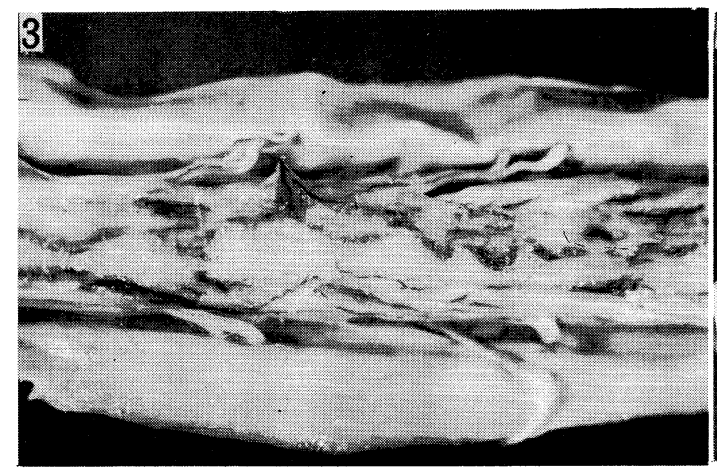

神経根部, 硬膜部の膠様, 結節状肥厚（腰䯣神経）。

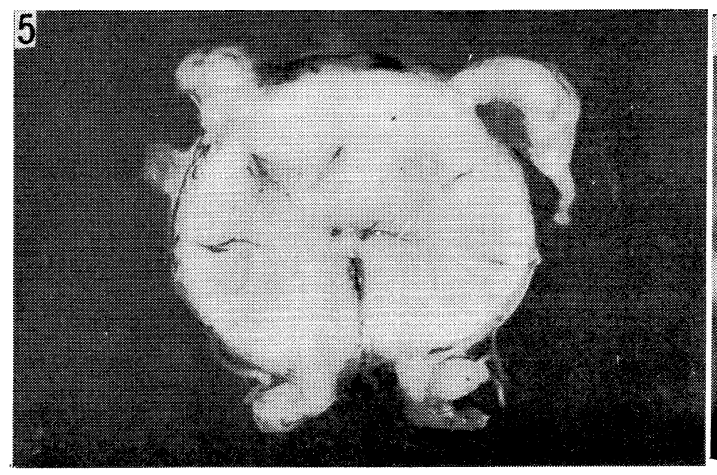

前, 後根の灰白色膠様肥厚と軟膜の混濁肥厚，実質には血

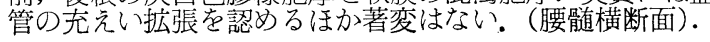

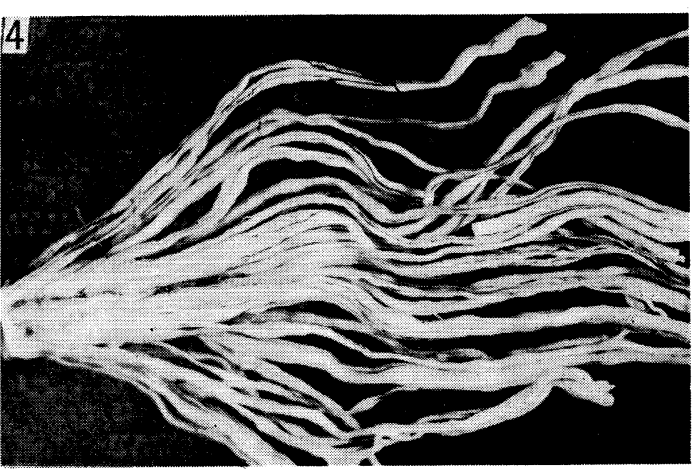

神経束のビゅず状, 膠様肥厚 (馬尾神経).

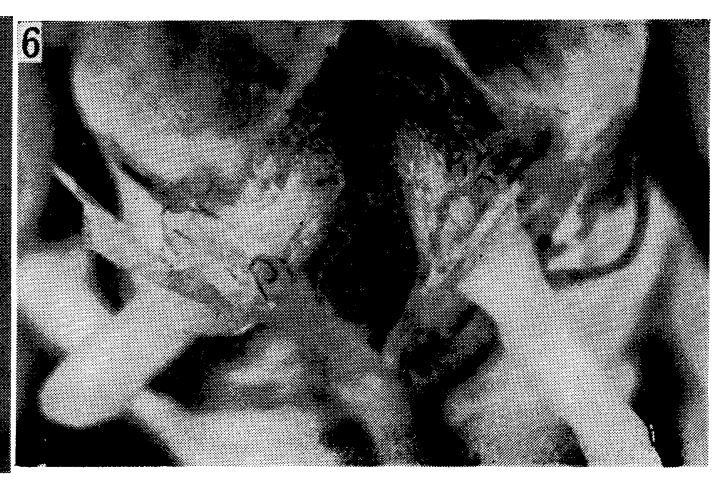

膠様外観を示し，口径の著明な増加をみ 万两側動眼神経根部. 
病理組織学的所見

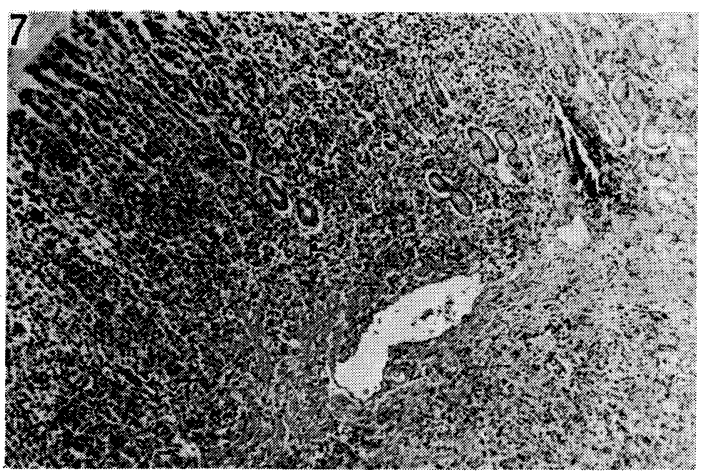

癌細胞のびまん性浸潤により肥厚を示す粘膜層と 粘膜下織への浸潤 (胃粘膜). HE染色, $\times 40$

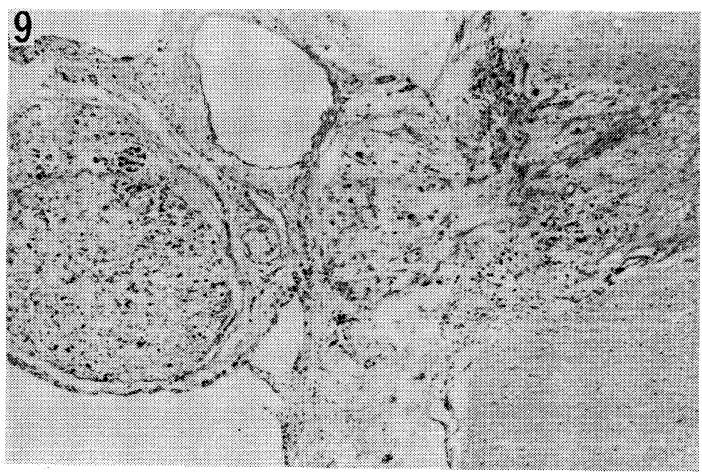

神経根, 軟膜および䏑髄漏斗部に浸潤する癌紐 胞 (腰㵦後根). $\mathrm{HE}$ 染色, $\times 40$.

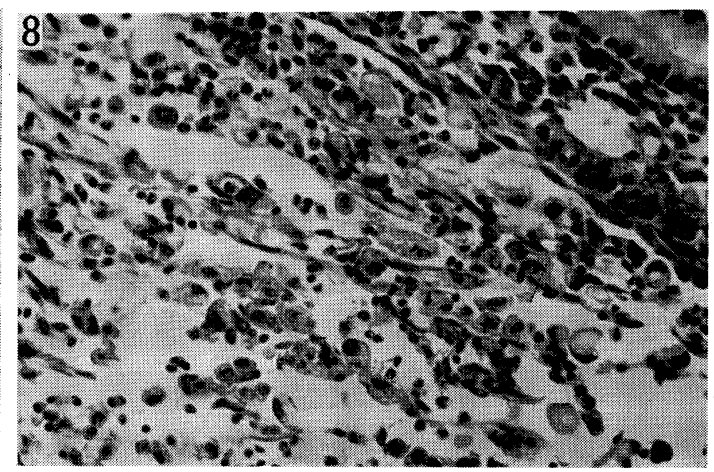

多数の印環紐胞を含み，特定配列を示さず，び まん性汇浸潤する腫瘍紐胞。 HE染色, ×400

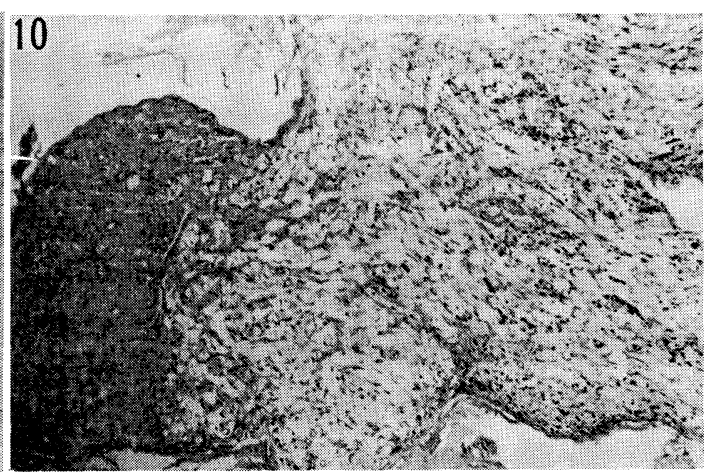

著明な癌細胞浸潤で置換された神経束，求心性に 実質内侵入守る所睍はなく, 比較的明加境界 されている(左動眼神経根部). $\mathrm{HE}$ 染色, $\times 40$

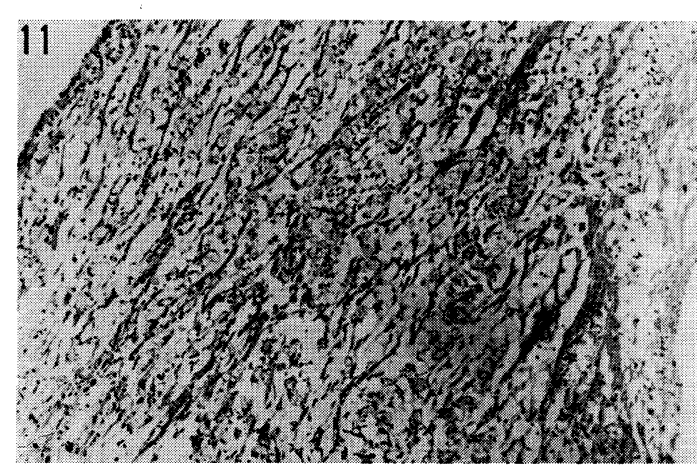

肉腿像で結節状肥厚を認めた馬尾神経. HE染色, $\times 40$

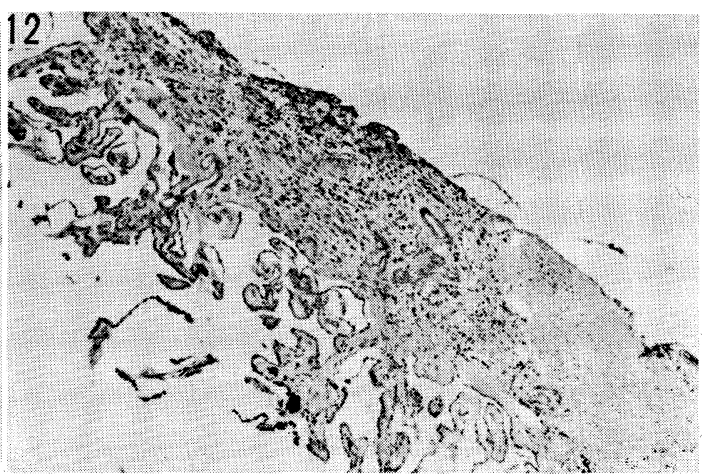

第 $\mathbf{V}$ 脳室壁および一部脈絡叢内に浸潤す る癌細胞. HE染色, $\times 100$ 